\title{
Effects of increased intra-abdominal pressure on the healing process after surgical stapling of the stomach of $\operatorname{dogs}{ }^{1}$
}

\author{
Efeitos da elevação da pressão intra-abdominal e de seu tempo de ação na \\ cicatrização de suturas mecânicas no estômago de cães
}

\author{
Nilson Chaves $\mathbf{J r}^{2}$, Luciene de Tassis Magalhães ${ }^{3}$, Ramiro Colleoni ${ }^{4}$, José Carlos Del Grande ${ }^{5}$ \\ 1. Research performed at Surgical Technique Laboratory and Experimental Surgery, University Severino Sombra, Educational Foundation Severino \\ Sombra (FUSVE), Vassouras, Rio de Janeiro and Federal University of São Paulo (UNIFESP), São Paulo, Brazil. \\ 2. Associate Professor, Medical School of University Severino Sombra, FUSVE, Vassouras, Rio de Janeiro, Brazil. \\ 3. Assistant Professor, Medical School of University Severino Sombra, FUSVE, Vassouras, Rio de Janeiro, Brazil. \\ 4. PhD, Affiliate Professor, Division of Gastrointestinal Surgery, UNIFESP, São Paulo, Brazil. \\ 5. PhD, Associate Professor, Division of Gastrointestinal Surgery, UNIFESP, São Paulo, Brazil.
}

\begin{abstract}
Purpose: To assess the initial healing after surgical stapling of the stomach using a linear cutting stapler and creating pneumoperitoneum $(12-14 \mathrm{mmHg}$ ) for 60 minutes or 120 minutes, and compare it with the healing of a staple line not submitted to increased pressure. Methods: A total of $30 \mathrm{dogs}$ were divided into three groups of 10 animals each: Group I (control group - surgical stapling), Group II (surgical stapling and increased intra-abdominal pressure for 60 minutes) and Group III (surgical stapling and increased intra-abdominal pressure for 120 minutes). All dogs were maintained under general anesthesia for two hours after surgical stapling. Seven days after surgery, the area around the staple line was macroscopically and microscopically examined. Results: The macroscopic examination of the samples $(n=30)$ did not show dehiscence, fistula or abscess. Adhesions between the omentum and the staple line were observed in all animals of Groups II and III $(n=20)$, which were significantly different from Group I $(\mathrm{p}=0.008 *)$. The histopathological analysis showed normal healing up to day 7 in the control animals $(n=10)$. When these results were compared with those of Groups II and III $(n=20)$, non-parametric tests revealed that there was a significant difference with regard to certain parameters of the early stages of healing, such as fibroblast migration $\left(\mathrm{p}=0.011^{*}\right)$, edema $(\mathrm{p}$ $<0.001 *)$ and congestion $\left(\mathrm{p}=0.011^{*}\right)$. These alterations affected reepithelization $(\mathrm{p}<0.001 *)$, and consequently the late stages of healing. Conclusions: Each group showed different healing stages, and the healing process was delayed in the groups submitted to increased pressure, especially in the group submitted to increased pressure for longer time. Key words: Pneumoperitoneum, Artificial. Wound Healing. Suture, Techniques. Stomach. Dogs.
\end{abstract}

\begin{abstract}
RESUMO
Objetivo: Avaliar os efeitos do pneumoperitônio com $\mathrm{CO}_{2}$ sobre a fase inicial da cicatrização ( $7^{\circ}$ dia) de uma sutura gástrica mecânica em cães, com diferentes tempos de aumento da pressão intra-abdominal. Métodos: Trinta cães foram divididos em três grupos e submetidos à laparotomia mediana e realização de uma sutura vertical na grande curvatura gástrica com grampeador linear cortante. Após a síntese abdominal, nos animais dos grupos II e III instalouse pneumoperitônio com $\mathrm{CO}_{2}$, permanecendo os animais com pressão intra-abdominal entre 12 e $14 \mathrm{mmHg}$ durante 60 minutos (grupo II) e 120 minutos (grupo III). Os animais foram reoperados no $7^{\circ}$ dia, para a avaliação macroscópica da cavidade abdominal e da sutura e retirada de um segmento gástrico contendo essa sutura para análise microscópica. Resultados: $\mathrm{Na}$ análise macroscópica observamos diferenças em relação a variável aderência, quando se comparou o grupo controle com os animais dos grupos II e III. Na análise microscópica da fase inicial do processo inflamatório as variáveis edema, congestão e reepitelização apresentaram maiores diferenças estatísticas quando comparados o Grupo Controle com os animais que sofreram a ação do pneumoperitônio. Este fenômeno foi mais evidente nos animais que permaneceram sob ação deste evento por período mais longo. Conclusões: As suturas submetidas ao aumento de pressão por período mais prolongado (120 minutos) apresentaram retardo do processo de cicatrização quando comparadas àquelas que sofreram essa ação por 60 minutos. Esse fato ficou ainda mais evidente quando as variáveis relacionadas ao processo de cicatrização foram comparadas com o grupo que não sofreu ação do pneumoperitônio. Descritores: Pneumoperitônio Artificial. Cicatrização de Feridas. Técnicas de Sutura. Estômago. Cães.
\end{abstract}




\section{Introduction}

The effects of increased intra-abdominal pressure on different systems, organs and tissues have been studied since the end of the 19th century. However, few articles had been published until the 1960s. Over the following decades, clinical and experimental studies showed the acute effects of increased intra-abdominal pressure on isolated organs and systems1, 2. After the 1990s, with improved techniques of minimally invasive surgery, researchers began to devote special attention to the increase in intra-abdominal pressure. Studies have shown that increased intra-abdominal pressure affects tissue perfusion, leading to changes in the blood flow on the wall of abdominal organs and causing tissue dysfunction3. Several studies have investigated the effects of increased intra-abdominal pressure on the cardiovascular and respiratory systems, the renal system, liver and abdominal wall4. Some studies have reported the effects of pneumoperitoneum on the healing of intestinal injury and anastomosis5,6. Very few studies, however, have investigated the effects of pneumoperitoneum on the healing process of other abdominal organs, especially the stomach. The purpose of this study was to investigate the effects of pneumoperitoneum with $\mathrm{CO} 2$ on the healing process after surgical stapling of the stomachs of dogs. Increased pressure was maintained for different periods of time, and the standard of comparison was a staple line not submitted to increased pressure.

\section{Methods}

A total of 30 mongrel dogs (Canis familiaris) were used in this study. The dogs were male, weighed between 13.1 and $14.3 \mathrm{~kg}$, and were donated by the laboratory animal facility of the Department of Operative Technique and Experimental Surgery, University of Severino Sombra, Vassouras, Rio de Janeiro. The animals were kept in an environment with natural light and proper temperature, and were given dog food and water. The dogs were randomly divided into three groups:

Group I: control group $(\mathrm{n}=10)$;

Group II: animals submitted to surgical stapling and pneumoperitoneum with a pressure of 12 to $14 \mathrm{mmHg}$ for 60 minutes $(\mathrm{n}=10)$;

Group III: animals submitted to surgical stapling and pneumoperitoneum with a pressure of 12 to $14 \mathrm{mmHg}$ for 120 minutes $(\mathrm{n}=10)$.

Anesthesia was induced through inhalation of sodium thiopental $(2.5 \%$ - dose of $10-15 \mathrm{mg} / \mathrm{kg})$ and maintained through inhalation of $1 \%$ halothane and oxygen. A midline incision was made in the supraumbilical region and the stomach was exposed. Then, a vertical staple line was placed using a linear cutting stapler (ENDO GIA ${ }^{\mathrm{TM}}$, with a $60 \mathrm{~mm}$ cartridge) on the greater curvature of the stomach, starting at the His angle, and parallel to the lesser curvature, forming a gastric tube. The application site was checked for hemostasis and the time taken to perform this procedure was recorded for all groups. In animals from groups II and III, a subxiphoid puncture was performed to place a Veress needle and create pneumoperitoneum. The abdominal cavity was then closed; a continuous suture was placed on the peritoneum and aponeurosis, and an interrupted suture was placed on the skin using nylon monofilament suture. After the abdominal wall was sutured, carbon dioxide was insufflated through the needle for creation of pneumoperitoneum in animals of Groups II and III. Intra-abdominal pressure was monitored using a digital manometer, and maintained between 12 and $14 \mathrm{mmHg}$ for 60 minutes (Group II) or 120 minutes (Group III). After that, the pneumoperitoneum was deflated. All animals from groups I, II and III were maintained under general anesthesia for 120 minutes after closure of the abdominal wall. The dogs underwent laparotomy again after seven days, and the same procedures were followed regarding anesthesia and incision. The peritoneal cavity and the staple line were inspected. Macroscopically, the following were considered: presence or absence of dehiscence, abscess or fistula, presence of adhesions between the omentum and the staple line, and adhesions between the tissue edges. Factors $\mathrm{A}$ and $\mathrm{B}$ were used to qualitatively describe the findings with different scores, as follows7,8: Factor A: Adhesions between the omentum and the staple line

$$
\begin{aligned}
& 0=\text { no adhesions } \\
& 1=\text { partial adhesions } \\
& 2=\text { extensive adhesions }
\end{aligned}
$$

Factor B: Adhesions between the tissue edges

$0=$ no adhesions

1 = filmy adhesions, easily separated with gentle traction

$2=$ dense adhesions, requiring significant traction or sharp dissection to separate

For statistical analysis and to facilitate interpretation of results, scores were assigned to Factors A and B. Thus, the higher the score for Factor A, the higher the number of adhesions. The higher the score for Factor B, the more severe the adhesions. After the macroscopic examination, samples were collected at the site where the staple line had been placed for microscopic examination. The samples were fixed with 5\% formaldehyde, embedded in paraffin and sliced into sections which were stained with hematoxylin and eosin. The histological features of acute inflammation were assessed and described as follows9:

Factor C: Acute inflammation

Prevalence of inflammatory cells:

$1=$ polymorphonuclear neutrophils and eosinophils (PMN). 
2 = mononuclear lymphocytes and histiocytes $(\mathrm{MN})$. Fibroblast activity (FBL)

$0=$ absent $\quad 1=$ mild $\quad 2=$ moderate $3=$ increased Neovascularization (NEO)

$0=$ absent $\quad 1=$ mild $\quad 2=$ moderate $3=$ increased

Congestion (CON)

$3=$ absent $\quad 2=$ mild $\quad 1=$ moderate $\quad 0=$ severe

Edema (EDM)

$3=$ absent $\quad 2=$ mild $\quad 1=$ moderate $\quad 0=$ severe

Reepithelization (REEP)

$0=$ absent $\quad 1=$ incomplete $\quad 2=$ complete

For cell count, Zeiss lenses were used (10X) with a reticle containing 25 squares. This grid was projected over the portion of the slides corresponding to the middle of the staple line, and the cells were counted. For each slide, the count was performed in ten different squares. For statistical analysis and to facilitate the interpretation of results, scores were assigned to Factor $\mathrm{C}$. The higher the score obtained, the better the healing. The statistical analysis was based on the variables studied. Because of the skewed distribution of variables and the number of animals in each group, nonparametric tests were employed: Mann-Whitney, KruskalWallis and Pearson's chi-squared tests. Fisher's exact test was also employed when there was at least one expected frequency of less than five. The results were considered statistically significant when $\mathrm{p}<0.05$, and significant values were marked with an asterisk.

\section{Results}

The sample studied was considered homogeneous with regard to weight. The average weight was $13.7 \mathrm{~kg}$, $13.8 \mathrm{~kg}$ and $13.6 \mathrm{~kg}$ for Groups I, II and III, respectively. Duration of surgery ranged from 20 to 27 minutes, with no significant difference between groups. No deaths occurred. No dehiscence, fistula or abscess was found upon macroscopic analysis. Scores obtained for Factor A were 6, 17 and 18 for Groups I, II and III, respectively. This indicated the presence of a greater number of adhesions in animals submitted to increased intra-abdominal pressure. Scores obtained for Factor B were 8, 16 and 18 for Groups I, II and III, respectively. This indicated the presence of severe adhesions between tissue edges in animals submitted to pneumoperitoneum. Tables 1 and 2 shows the score for each animal of each group. To compare adhesion formation and severity between the control group $(n=10)$ and Groups II and III $(\mathrm{n}=20)$, the Mann-Whitney non-parametric test was employed. Fisher's exact test yielded $\mathrm{p}$ values of 0.008* and 0.103 for Factors A and B, respectively. With regard to the microscopic examination of the inflammatory process (Factor C), the total score for Groups I, II and III was 146, 97 and 54, respectively. This indicated better healing in the control animals, which were not submitted to pneumoperitoneum. Table 3 shows the score assigned to each animal of Groups I, II and III for the variables analyzed.

TABLE 1 - Score for Group I, II and III - Factor A (adhesions between the omentum and the staple line)

\begin{tabular}{|c|c|c|c|c|c|c|c|c|c|c|c|c|}
\hline \multirow[t]{2}{*}{ ANIMAL } & \multicolumn{3}{|c|}{ GRUPO I } & \multirow[t]{2}{*}{ Score } & \multicolumn{3}{|c|}{ GRUPO II } & \multirow[t]{2}{*}{ Score } & \multicolumn{3}{|c|}{ GRUPO III } & \multirow[t]{2}{*}{ Score } \\
\hline & NA & PA & EA & & NA & PA & EA & & NA & PA & EA & \\
\hline 1 & $X$ & & & 0 & & $X$ & & 1 & & & $\mathrm{X}$ & 2 \\
\hline 2 & $X$ & & & 0 & & & $X$ & 2 & & & $X$ & 2 \\
\hline 3 & & $X$ & & 1 & & & $X$ & 2 & & & $X$ & 2 \\
\hline 4 & $X$ & & & 0 & & $X$ & & 1 & & & $X$ & 2 \\
\hline 5 & & $X$ & & 1 & & & $X$ & 2 & & $\mathrm{X}$ & & 1 \\
\hline 6 & & $X$ & & 1 & & & $X$ & 2 & & & $X$ & 2 \\
\hline 7 & $X$ & & & 0 & & $X$ & & 1 & & & $\mathrm{X}$ & 2 \\
\hline 8 & & $X$ & & 1 & & & $X$ & 2 & & & $X$ & 2 \\
\hline 9 & & $X$ & & 1 & & & $X$ & 2 & & $X$ & & 1 \\
\hline 10 & & $\mathrm{X}$ & & 1 & & & $\mathrm{X}$ & 2 & & & $\mathrm{X}$ & 2 \\
\hline TOTAL & & & & 06 & & & & 17 & & & & 18 \\
\hline
\end{tabular}

NA - no adhesions; PA - partial adhesions; EA - extensive adhesions 
TABLE 2 - Score for Group I, II and III - Factor B Factor B (adhesions between tissue edges)

\begin{tabular}{|c|c|c|c|c|c|c|c|c|c|c|c|c|}
\hline \multirow[t]{2}{*}{ ANIMAL } & \multicolumn{3}{|c|}{ GRUPO I } & \multirow[t]{2}{*}{ Score } & \multicolumn{3}{|c|}{ GRUPO II } & \multirow[t]{2}{*}{ Score } & \multicolumn{3}{|c|}{ GRUPO III } & \multirow[t]{2}{*}{ Score } \\
\hline & NA & FA & DA & & NA & FA & DA & & NA & FA & DA & \\
\hline 1 & & $\mathrm{X}$ & & 1 & & $\mathrm{X}$ & & 1 & & & $\mathrm{X}$ & 2 \\
\hline 2 & $X$ & & & 0 & & & $\mathrm{X}$ & 2 & & & $\mathrm{X}$ & 2 \\
\hline 3 & & $\mathrm{X}$ & & 1 & & & $X$ & 2 & & & $X$ & 2 \\
\hline 4 & & $\mathrm{X}$ & & 1 & & $\mathrm{X}$ & & 1 & & & $X$ & 2 \\
\hline 5 & & $X$ & & 1 & & & $X$ & 2 & & $X$ & & 1 \\
\hline 6 & & $X$ & & 1 & & & $X$ & 2 & & & $\mathrm{X}$ & 2 \\
\hline 7 & $\mathrm{X}$ & & & 0 & & $\mathrm{X}$ & & 1 & & & $\mathrm{X}$ & 2 \\
\hline 8 & & $\mathrm{X}$ & & 1 & & & $\mathrm{X}$ & 2 & & & $X$ & 2 \\
\hline 9 & & $\mathrm{X}$ & & 1 & & $\mathrm{X}$ & & 1 & & $\mathrm{X}$ & & 1 \\
\hline 10 & & $\mathrm{X}$ & & 1 & & & $X$ & 2 & & & $\mathrm{X}$ & 2 \\
\hline TOTAL & & & & 08 & & & & 16 & & & & 18 \\
\hline
\end{tabular}

NA - no adhesions; FA - filmy adhesions; DA - dense adhesions

TABLE 3 - Score for Group I, II and III Animals (acute inflammation)

\begin{tabular}{|c|c|c|c|c|c|c|c|c|c|c|c|c|c|c|c|c|c|c|c|c|c|}
\hline \multirow[t]{2}{*}{ ANIMAL } & \multicolumn{7}{|c|}{ Grupo I } & \multicolumn{7}{|c|}{ GRUPO II } & \multicolumn{7}{|c|}{ GRUPO III } \\
\hline & PN MN & $\mathrm{FB}$ & $\mathrm{NE}$ & $\mathrm{CO}$ & ED & $\mathrm{RE}$ & $\mathrm{SC}$ & PN MN & $\mathrm{FB}$ & $\mathrm{NE}$ & $\mathrm{CO}$ & ED & $\mathrm{RE}$ & $\mathrm{SC}$ & PN & MN FB & $\mathrm{NE}$ & $\mathrm{CO}$ & ED & $\mathrm{RE}$ & $\mathrm{SC}$ \\
\hline 1 & 1 & 3 & 3 & 3 & 3 & 2 & 15 & 1 & 2 & 2 & 2 & 1 & 1 & 9 & 1 & 1 & 2 & 1 & 0 & 1 & 6 \\
\hline 2 & 1 & 2 & 3 & 3 & 3 & 2 & 14 & 1 & 2 & 2 & 2 & 1 & 1 & 9 & 1 & 1 & 2 & 0 & 0 & 1 & 5 \\
\hline 3 & 1 & 3 & 3 & 3 & 3 & 2 & 15 & 1 & 2 & 2 & 2 & 1 & 1 & 9 & 1 & 1 & 2 & 0 & 0 & 1 & 5 \\
\hline 4 & 1 & 2 & 3 & 3 & 3 & 2 & 14 & 1 & 2 & 2 & 2 & 1 & 1 & 9 & 1 & 1 & 2 & 1 & 0 & 1 & 6 \\
\hline 5 & 1 & 3 & 3 & 3 & 3 & 2 & 15 & 1 & 2 & 2 & 2 & 1 & 1 & 9 & 1 & 1 & 1 & 0 & 0 & 1 & 4 \\
\hline 6 & 1 & 3 & 3 & 3 & 3 & 2 & 15 & 1 & 2 & 2 & 2 & 1 & 1 & 9 & 1 & 1 & 2 & 1 & 0 & 1 & 6 \\
\hline 7 & 1 & 2 & 3 & 3 & 3 & 2 & 14 & 1 & 2 & 3 & 2 & 1 & 1 & 10 & 1 & 1 & 2 & 1 & 0 & 1 & 6 \\
\hline 8 & 1 & 2 & 3 & 3 & 3 & 2 & 14 & 2 & 3 & 3 & 2 & 1 & 1 & 12 & 1 & 1 & 2 & 1 & 0 & 1 & 6 \\
\hline 9 & 1 & 3 & 3 & 3 & 3 & 2 & 15 & 1 & 2 & 2 & 2 & 1 & 1 & 9 & 1 & 1 & 1 & 0 & 0 & 1 & 4 \\
\hline 10 & 1 & 3 & 3 & 3 & 3 & 2 & 15 & 2 & 3 & 3 & 2 & 1 & 1 & 12 & 1 & 1 & 2 & 1 & 0 & 1 & 6 \\
\hline
\end{tabular}

PN - polymorphonuclear cells; MN - mononuclear cells; FB - fibroblast activity; NE - neovascularization; CO - vascular congestion; ED - edema; $\mathrm{RE}$ - reepithelization SC - score 
TABLE 4 - Variables of Factors A, B and C, with respective p values

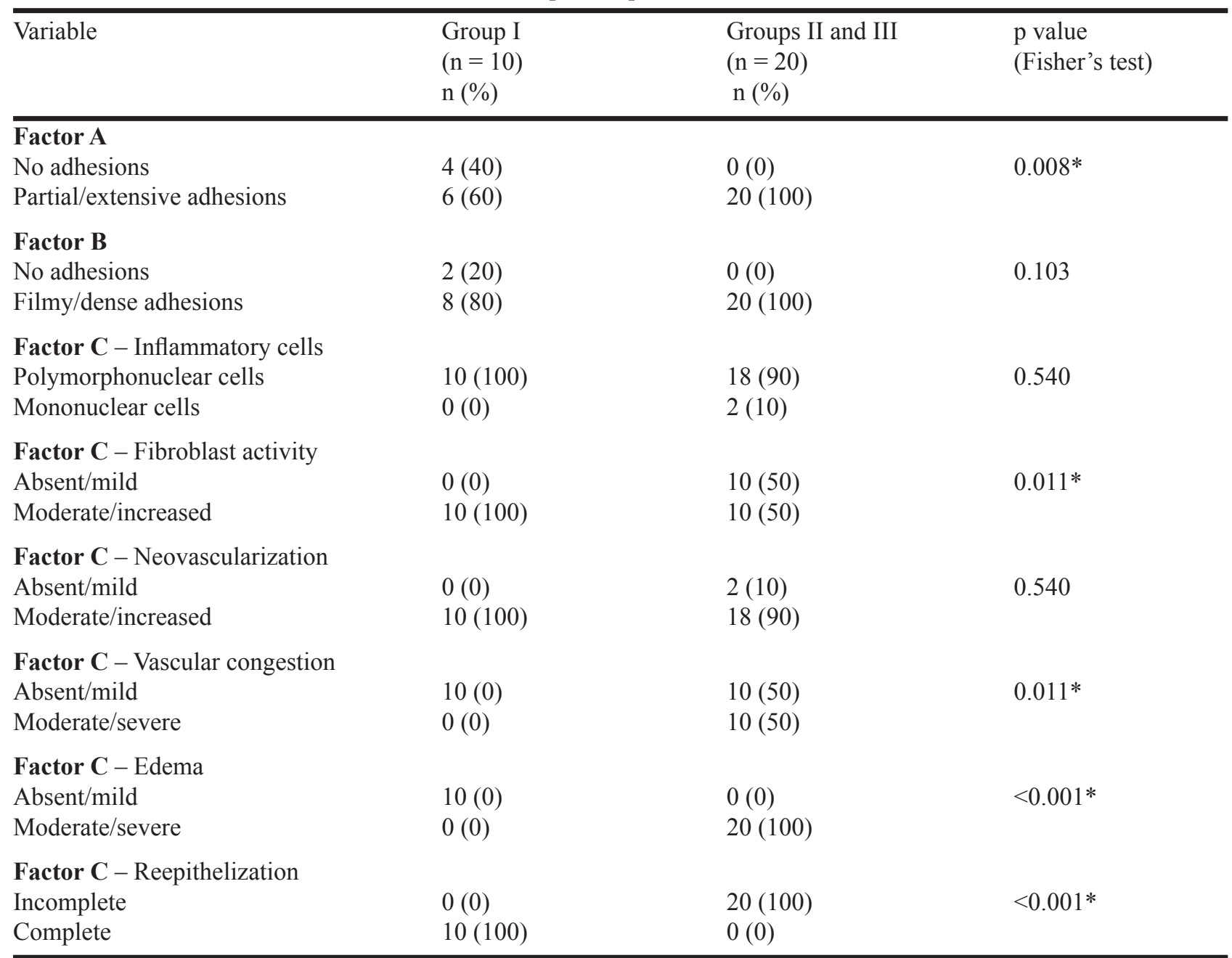

TABLE 5 - Variables of factor $C$ with median values and respective $p$ values

\begin{tabular}{|c|c|c|c|c|c|c|}
\hline \multirow[b]{2}{*}{ Group } & \multirow[b]{2}{*}{ Inflammatory cells } & \multicolumn{4}{|c|}{ Variables - median (minimum-maximum) } & \multirow[b]{2}{*}{ REEP } \\
\hline & & FBL & NEO & $\mathrm{CON}$ & EDM & \\
\hline I & $0(0-0)$ & $3(2-3)$ & $3(3-3)$ & $3(3-3)$ & $3(3-3)$ & $2(2-2)$ \\
\hline II & $0(0-1)$ & $2(2-3)$ & $2(2-3)$ & $2(2-2)$ & $1(1-1)$ & $1(1-1)$ \\
\hline III & $0(0-0)$ & $1(1-1)$ & $2(1-2)$ & $1(0-1)$ & $0(0-0)$ & $1(1-1)$ \\
\hline $\begin{array}{l}\text { Kruskal-Wallis } \\
\text { I x II x III }\end{array}$ & 0.126 & $<0.001 *$ & $<0.001^{*}$ & $<0.001^{*}$ & $<0.001^{*}$ & $<0.001^{*}$ \\
\hline $\begin{array}{l}\text { Mann-Whitney } \\
\text { I x II }\end{array}$ & 0.146 & 0.075 & $0.004 *$ & $<0.001^{*}$ & $<0.001 *$ & $<0.001 *$ \\
\hline $\begin{array}{l}\text { Mann-Whitney } \\
\text { I x III }\end{array}$ & 1.000 & $<0.001 *$ & $<0.001^{*}$ & $<0.001 *$ & $<0.001 *$ & $<0.001^{*}$ \\
\hline $\begin{array}{l}\text { Mann-Whitney } \\
\text { II x III }\end{array}$ & 0.146 & $<0.001 *$ & $0.015^{*}$ & $<0.001 *$ & $<0.001 *$ & 1.000 \\
\hline
\end{tabular}

FBL - fibroblast activity; NEO - neovascularization; CON - vascular congestion; EDM - edema; REEP - reepithelization 


\section{Discussion}

Videolaparoscopy has been increasingly used for diagnosis and treatment, which has led to the discussion of the postoperative consequences of pneumoperitoneum. Special attention has been given to the increased intraabdominal pressure caused by insufflation with $\mathrm{CO} 2$. Studies have been carried out to show the effects of increased pressure on the cardiovascular and respiratory systems, the renal system, liver and abdominal wall4. It became known that increased intra-abdominal pressure affected tissue perfusion, tissue function and blood flow on the wall of abdominal organs2,3. Some studies have investigated the effects of increased intra-abdominal pressure on the healing of bowel injury and anastomosis 5,6. Few studies have investigated the effects of increased pressure on sutures placed on other intra-abdominal organs, especially on the stomach. There are no studies in the literature that describe the effects of pneumoperitoneum with $\mathrm{CO} 2$ on a gastric staple line, particularly with different values of pressure and periods of time. In our study, the choice of a pressure of $12-14 \mathrm{mmHg}$ for the creation of pneumoperitoneum was based on the pressure values commonly used in laparoscopic procedures. These pressure values allow good visualization and manipulation of anatomical structures, and do not significantly affect cardiopulmonary functions4. Group II was submitted to pneumoperitoneum for 60 minutes because studies have shown that increased pressure for 60 minutes may affect blood flow on the walls of gastrointestinal organs. Group III was submitted to pneumoperitoneum for 120 minutes because studies have shown that the maintenance of increased pressure for 120 minutes may affect the healing of intestinal anastomoses6. The macroscopical parameters analyzed in the present study were the presence of dehiscence, fistula and abscess. These parameters were used because they are common postoperative complications and are closely related to risk factors such as edema caused by excessive manipulation of organs, increased intraabdominal pressure and inadequate blood supply to tissue edges 7. The same risk factors are associated with adhesion formation, which was also examined macroscopically. The microscopic analysis of the samples was carried out seven days after the surgical procedure. This postoperative period was chosen because after seven days acute inflammatory cells can be observed. The prevalence of polymorphonuclear cells or mononuclear cells, fibroblast activity and neovascularization was microscopically examined. These factors contribute to reepithelization in the early healing phase. Other factors microscopically analyzed were edema and congestion. Severe edema and congestion may lead to inadequate tissue perfusion and, consequently, delayed reepithelialization8,9. The use of scores for both macroscopic and microscopic examinations was based on published studies that assessed blood flow and healing of anastomotic sites10, 11 e 12 . After seven days, the dogs underwent laparotomy again. Wound dehiscence, abscess and fistula were not observed in any animal. The pressure values and periods of time used in this study did not cause the aforementioned complications. Thus, none of these variables was submitted to statistical analysis. Adhesions were observed in most animals, and two variables were analyzed: presence of adhesions to the staple line and severity of adhesions between tissue edges. With regard to the presence of adhesions, the Mann-Whitney test was used to compare Group I ( $\mathrm{n}=10)$ with Groups II and III $(n=20)$, and Fisher's exact test yielded a $\mathrm{p}$ value of $0.8 \%$. Severity of adhesions between tissue edges was similar in most animals, which means that this variable was not statistically significant. Some authors have used this variable as a parameter to assess anastomoses; dense adhesions may indicate the need for more protection at the anastomotic site13. Adhesions should not always be regarded as undesirable, because they may increase resistance at the suture line during the first postoperative days. They may also increase local blood flow, increasing the supply of oxygen and nutrients14. The analysis of the total number of animals with adhesions led us to believe that this response might be the body's attempt to increase local blood flow, recognizing the need for increased protection at the site. Each variable of Factor $\mathrm{C}$ was analyzed individually using the Mann-Whitney test. Group I was compared with Groups II and III with regard to the prevalence of inflammatory cells. The $\mathrm{p}$ value obtained was $54 \%$, showing a prevalence of polymorphonuclear cells in all three groups. Median values (minimum and maximum) were analyzed. No significant difference was observed when groups were compared separately or in pairs with regard to the prevalence of inflammatory cells, since polymorphonuclear cells were prevalent in all groups. This is in agreement with other studies which suggested that polymorphonuclear cells arrive and stay at the healing site for longer when there is tissue contamination or damage. Tissue contamination and damage are related to chemotactic factors, which account for the presence of polymorphonuclear cells at the healing site14. In our study, no signs of infection were observed in any animal. Therefore, chemotaxis may be related to the presence of metal staples at the wound site. The staples acted as a foreign body, which probably led to the prevalence of polymorphonuclear cells at the site for up to seven days in the control animals. Moreover, in Groups II and III, the pneumoperitoneum may have affected the staple line, and this may have contributed to the increased prevalence of polymorphonuclear cells. The persistence of these cells may have affected the healing process by delaying the appearance of macrophages, which stimulate fibroblast response and appear at the healing site when polymorphonuclear cells disappear8,9. When fibroblast activity was analyzed comparing Group I with Groups II and III, the $\mathrm{p}$ value obtained was $1.1 \%$. When the groups were compared separately, a p value of $0.1 \%$ was observed, 
showing a more significant difference. Group I animals showed normal neovascularization and no vascular congestion during the healing process. New vessels without congestion were observed, leading to normal cell migration and, in turn, vessel maturation. In animals from Groups II and III, reduced neovascularization and slow blood flow, shown by increased stasis, were observed. This was more evident in animals from Group III, and was probably due to the limited number of macrophages at the site. Mediators released by these cells would have stimulated angiogenesis if there had been a higher number of macrophages 15 . With regard to the variable congestion, when Group I was compared with Groups II and III, the non-parametric tests employed yielded a $p$ value of $1.1 \%$. When median values were compared, a $\mathrm{p}$ value of $0.1 \%$ was observed, which shows that the groups were significantly different with regard to congestion. It is likely that edema, caused by vascular stasis, was the main factor to impair the acute phase of healing. This was observed in dogs from Groups II and III. Edema increases the amount of water in the connective tissue around the extracellular matrix. The newly formed tissue can resist compressive forces, but the diffusion of nutrients, metabolites and hormones between blood and cell tissues is hindered16. Tissue edema was not observed in the control animals. The samples from animals of Groups II and III showed massive edema, which was more severe in Group III animals. According to the nonparametric tests used in this study, the groups were significantly different with regard to edema ( $p<0.1 \%$ in all analyses performed). The most significant difference in healing between groups was observed when the variable reepithelization was considered. Reepithelization was normal in all animals from Group I. This is expected seven days aftera surgical procedure9. In ourstudy, reepithelization in Groups II and III was probably affected by the severe edema and congestion observed. Some ischemic areas were present, which may be a consequence of the increased intra-abdominal pressure, of up to $14 \mathrm{mmHg}$, for as long as 120 minutes. These areas affected normal healing. Increased intra-abdominal pressure for 60 minutes may have led to impaired healing. When increased pressure was maintained for 120 minutes, congestion and edema were more severe. It is well known that these two factors may impair wound healing; thus the maintenance of increased pressure for longer may have led to further delayed healing. Congestion and edema, which were affected by increased pressure and time of pneumoperitoneum, probably delayed reepithelization. The statistical analysis of this variable showed a significant difference when groups were compared separately, when Groups I and II were compared, and when Groups I and III were compared ( $p<0.1 \%)$. However, no significant difference was observed when Groups II and III were compared with regard to reepithelization. This experimental study investigated the acute phase of healing and described the macroscopical features and the findings examined by optical microscopy seven days after the surgical procedure. Our results indicate that pneumoperitoneum impairs healing. In addition, a longer period of increased pressure will have more negative effects on the healing process after gastric stapling. It can be suggested that laparoscopic procedures with creation of pneumoperitoneum with $\mathrm{CO} 2$ and suturing be carried out with careful monitoring of the intraperitoneal pressure. The findings of the present study suggest the need for further investigations to assess technical variations to reduce the negative effects of pneumoperitoneum on the healing process, such as interruptions during the surgical procedure with reduction in pressure or the use of other gases.

\section{Conclusions}

Based on the macroscopic and microscopic features of the healing process after gastric stapling in two groups of animals submitted to pneumoperitoneum for different periods of time, and comparing these findings with those from another group not submitted to pneumoperitoneum, we can conclude that, on the seventh postoperative day:

1. The healing process observed after gastric stapling was different between the three groups;

2. Delayed healing was observed in the animals submitted to increased intra-abdominal pressure;

3. The healing process in animals submitted to pneumoperitoneum for 120 minutes was further delayed when compared with that of animals submitted to pneumoperitoneum for 60 minutes. All animals submitted to pneumoperitoneum showed delayed healing when compared with control animals.

\section{References}

1. Ivankovich AD, Miletich DJ, Albrecht RF, Heyman HJ, Bonnet RF. Cardiovascular effects of intraperitoneal insufflation with carbon dioxide and nitrous oxide in the dog. Anesthesiology. 1975;42:281-7.

2. Caldwell CB, Ricotta JJ. Changes in visceral blood flow with elevated intraabdominal pressure. J Surg Res. 1987;43:14-20.

3. Diebel LN, Wilson RF, Dulchavsky SA: Effect of increased intra-abdominal pressure on hepatic arterial, portal venous, and hepatic microcirculatory blood flow. J Trauma. 1992;33:279-82.

4. Cheatham ML. Intra-abdominal hypertension and abdominal compartment syndrome. New Horizons. 1999;7:96-115.

5. Kologlu M, Sayek I, Kologlu BL, Eng C, Onat D. Effect of persistently elevated intraabdominal pressure on healing of colonic anastomoses. Am J Surg. 1999;178:293-7. 
6. Polat C, Arikan Y, Vatansev C, Akbulut G, Yilmaz S, Dilek FH, Gokçe O. The effects of increased intraabdominal pressure on colonic anastomoses. Surg Endosc. 2002;16(9):1314-9.

7. Riou JP, Cohen JR, Johnson H Jr: Factors influencing wound dehiscence. Am J Surg. 1992;163:324-30

8. Witte MB, Barbul A. General principles of wound healing. Surg Clin North Am. 1997;77:509-28.

9. Nwomeh BC, Olutoye OO, Diegelmann RF, and Cohen IK:Biologyofwoundhealing.J.SurgPathol.1997;2:1-19.

10. Houston KA, Rotstein OD. Fibrin sealant in high-risk colonic anastomoses. Arch. Surg. 1988;123:230-4.

11. Basu S, Marine CP, Bauman FG, Shirazian D, Damiani P, Robertazzi R, Jacobowitz IJ, Acinapura A, Cunninghan JN. Comparative study of biological glues: cryoprecipitate glue, two-component fibrin sealant, and “french" glue. Ann. Thorac. Surg. 1995;60:1255-62.
12. Greca FH, Biondo-Simões MLP, de Paula JB, de Noronha L, Ferreira da Cunha LS, Baggio PV, Bittencourt FO. Correlação entre o fluxo sangüíneo intestinal e a cicatrização de anastomoses colônicas: estudo experimental em cães. Acta Cir Bras. 2000;15(supl. 3):88-94.

13. Zaporozhets AA. Physical and biologic impermeability of intestinal sutures in the first twenty-four hours after operations on the gastrointestinal tract. Surgery. 1992;112:940-2.

14. Marshall JC: Neutrophils in the pathogenesis of sepsis. Crit Care Med. 2005;33(12):502-5.

15. Trengove NJ, Bielefeldt-Ohmann H, Stacey MC. Mitogenic activity and cytokines levels in non-healing chronic leg ulcers. Wound Repair Regen. 2000;8:13-25.

16. Holly SP, Larson MK, Parise LV. Multiple roles of integrin in cell motility. Exp Cell Res. 2000;69:74.

\section{Correspondence:}

Nilson Chaves Junior

Rua Luiz Tambasco, 113

27700 -000 Vassouras - Rio de Janeiro Brazil

Received: March 14, 2007
Conflict of interest: none Financial source: none

Review: May 15, 2007

Accepted: June 14, 2007

\section{How to cite this article}

Chaves Jr N, Magalhães LT, Colleoni R, Del Grande JC. Effects of increased intra-abdominal pressure on the healing process after surgical stapling of the stomach of dogs. Acta Cir Bras. [serial on the Internet] 2007 Sept-Oct;22(5). Available from URL: http://www.scielo.br/acb 